\title{
Isolation, Identification and Characterization of Rabbit Caecal Mucinolytic Bacteria
}

\author{
K. SIROTEK ${ }^{1}$, E. SANTOS ${ }^{2}$, V. BENDA ${ }^{3}$, M. MAROUNEK ${ }^{1}$ \\ ${ }^{1}$ Institute of Animal Physiology and Genetics, Czech Academy of Sciences, \\ Prague, Czech Republic \\ 2 Agrarian School, Polytechnic Institute of Viseu, Viseu, Portugal \\ ${ }^{3}$ Institute of Chemical Technology, Department of Biochemistry and Microbiology, \\ Prague, Czech Republic \\ Received July 15, 2002 \\ Accepted March 25, 2003
}

\section{Abstract}

Sirotek K., E. Santos, V. Benda, M. Marounek: Isolation, Identification and Characterization of Rabbit Caecal Mucinolytic Bacteria. Acta Vet. Brno 2003, 72: 365-370.

The aim of our study was to isolate, identify and characterize mucinolytic bacteria from the rabbit caecum. Two hundred and thirty mucin-grown colonies from the caecal contents of 7 rabbits were examined microscopically after the Gram staining. Gram-negative irregular rods were the most numerous mucinolytic isolates $(34.1 \%)$, followed by gram-negative cocci and short rods $(22.5 \%)$, gram-positive rods $(17.3 \%)$, gram-positive cocci $(16.6 \%)$ and gram-positive sporeforming rods $(9.5 \%)$. An attempt was done to identify 31 typical isolates on basis of their morphology, biochemical characteristics and production of metabolites. In addition, bacterial cells were hybridized with fluorescently labelled probes for Bacteroides/Prevotella and Clostridium genus. Four isolates were identified at the species level as Mitsuokella multiacidus, three isolates as Bacteroides capillosus and one isolate as Actinomyces izraeli. All isolates except the last one belong to the Bacteroidaceae family. One strain could be assigned to the Bacteroides/Prevotella genus on basis of the hybridization test. Other mucinolytic isolates were not identified as their characteristics did not correspond to any previously described bacterial species. No Clostridium sp. strain was detected. In two M. multiacidus strains high activities of extracellular mucin lyases were found. The $\mathrm{pH}$-optimum of lyases was 6.2. Calcium cations were necessary for their optimal function. This work extends general knowledge about fermentation of carbohydrate and nitrogen substrates in rabbit caecum.

Rabbit, caecum, mucin, bacteria

Mucin is a glycoprotein present in the mucosal layer lining mammalian gastrointestinal, respiratory and reproductive tract. The carbohydrate moiety can be either an acidic mucopolysaccharide containing uronic acids and hexosamines or an oligosaccharide containing L-fucose and sialic acid (Salyers and Leedle 1983). Mucin composition is tissue specific and differs in different animal species. Mucin is a part of the defense mechanism as it prevents bacteria, viruses and dietary lectins from attaching to the intestinal or other epithelium. Another mucin function is the protection of the mucosal epithelium against acidic and proteolytic damage in the stomach and intestine. In the digestive tract, mucin insures a smooth passage of the foodpulp. Holmes et al. (1974) observed in pigs that large amounts of mucin were not digested in the small intestine, but fermented in the hindgut. Microorganisms responsible for mucin fermentation in the human colon are partially known. Salyers et al. (1977) isolated from the human colon several Bacteroides strains able to degrade mucins and plant polysaccharides. Baylis s and Houston (1984) identified some mucin fermenters as members of the Bacteroides genus, other resembled Bifidobacterium sp., Clostridium septicum, and Eubacterium sp. Crociani et al. (1994) found that only

Address for correspondence:

Ing. Kamil Sirotek

Institute of Animal Physiology and Genetics

Czech Academy of Sciences
Vídeňská 1083, 14220 Prague 10, Czech Republic
Phone: +420267090508

Fax: +420267090500

E-mail: sirotekkamil@ seznam.cz 
Bifidobacterium bifidum strains fermented gastric mucin among 29 species of bifidobacteria tested. Mucin fermenters from the digestive tract of herbivores are almost unknown. Hill (1986) has shown that bacteria isolated from the rabbit caecum belonging to the Bacteroides genus were most active in digestion of mucin in vitro. In in vitro incubations of the rabbit caecal contents, mucin was converted into mixture of metabolites, yielding more volatile fatty acids and methane than plant proteins and casein (Marounek et al. 2000). The aim of our study was to isolate, identify and characterize mucinolytic bacteria from the rabbit caecum.

\section{Materials and Methods}

Animals and diets

Three rabbits were purchased from a commercial farm with 200 does (Hyplus genotype). Four crossbred rabbits were obtained from a small farm (backyard system). Commercial rabbits were fed ad libitum a granulated feed containing alfalfa meal, barley, oat, wheat bran and extracted oilseed meals as the principal components. Two crossbred rabbits were fed with wheat (30 - $40 \mathrm{~g} / \mathrm{day})$, apples $(200-300 \mathrm{~g} / \mathrm{d})$ and meadow hay ad libitum. Another two crossbred rabbits were fed with wheat $(30-40 \mathrm{~g} / \mathrm{d})$ and grass ad libitum.

Enumeration, isolation and characterization of bacteria

Rabbits were killed by cervical dislocation, their caecal contents were aseptically collected, serially diluted and plated on Wilkins-Chalgren agar (Oxoid), containing 10\% caecal extract prepared according to Emaldi et al. (1979) and $0.4 \%$ porcine gastric mucin (Fluka). The plates were incubated anaerobically for 2 days at $39{ }^{\circ} \mathrm{C}$ in anaerostats (Anaerobic Plus System, Oxoid) under $\mathrm{CO}_{2} / \mathrm{H}_{2}(9: 1)$ atmosphere. The colonies were counted and the mean and standard deviation calculated. A total of 230 mucin-grown colonies were picked up at random and examined microscopically after the Gram staining. Typical isolates (31 strains) were tested for growth in $20 \%$ bile, $5 \% \mathrm{NaCl}$ and for catalase production (Faddin 1976). Their biochemical characteristics were determined using commercial tests Anaerotest 23 and Enterotest 24 from Lachema (Brno, Czech Rep.). End-products of glucose fermentation were estimated in cultures of bacteria grown in the Wilkins-Chalgren broth.

Fluorescence in situ hybridization (FISH)

An attempt was done to identify some isolates using the in situ hybrization. Two fluorescently labelled probes, 10-MC-H008 for Bacteroides/Prevotella and 10-MC-H009 for Clostridium genus were purchased from Microscreen BV (Groningen, The Netherlands). Bacteroides thetaiotamicron ATCC 29741 and Clostridium perfringens CNCTC 5459 were the control organisms. Overnight cultures were centrifuged and cells resuspended in $10 \mathrm{mM}$ phosphate buffer $(\mathrm{pH}=6.5)$ containing cysteine. $\mathrm{HCl}$ at $0.5 \mathrm{~g} / \mathrm{l}$. The "Fixative" $(0.1 \mathrm{ml})$ was added to resuspended cells $(0.9 \mathrm{ml})$ and incubated for $4 \mathrm{~h}$ at $4{ }^{\circ} \mathrm{C}$. After fixation, the cells were centrifuged and the pellet resuspended in $5.0 \mathrm{ml}$ of "MCPX1" buffer. Ten $\mu 1$ of the suspension were pipetted onto a microscope slide and spreaded over the glass surface. The spot was dried for $15 \mathrm{~min}$ at $45^{\circ} \mathrm{C}$ and dehydrated by submerging the slide in a graded ethanol series (50,75 and 100\% ethanol), for 2 min each. Ten $\mu$ l of "Hybridization mixture" were pipetted to the cell spot and covered with a cover glass. The microscope slide was placed in the prewarmed hybridization chamber and hybridized for $16 \mathrm{~h}$ at $45^{\circ} \mathrm{C}$ in the dark. After hybridization, the cells were washed for $20 \mathrm{~min}$ at $45^{\circ} \mathrm{C}$ by submerging the slide in $40 \mathrm{ml}$ of "MCW1" buffer. The surface was rinsed with sterile water and the slide dried in air. Six $\mu 1$ of "Mounting Fluid" were applied to the cells and covered with a cover glass. The samples were viewed by the E-800 Nikon epifluorescence microscope using $1000 \times$ magnification and appropriate excitation and emission filtres for FITC (fluorescein thiosocyanate; $495 / 520 \mathrm{~nm}$ ). Cells stain green due to the fluorescence of FITC.

Analyses

Volatile fatty acids were determined by gas-liquid chromatography on a column of Chromosorb WAW with $15 \%$ SP 1220 and $1 \% \mathrm{H}_{3} \mathrm{PO}_{4}$ (Supelco). Lactate, fumarate and succinate were methylated and estimated on a column of Supelcoport with $3 \%$ SP 2340 from the same firm. Concentration of protein was determined by the Lowry method (Herbert et al. 1971). The optical density of cultures was measured at $640 \mathrm{~nm}$.

Enzyme assays

Bacteria were grown in a vitamin-mineral medium prepared according to Marounek et al. (1993), supplemented with $0.1 \%$ yeast extract and $10 \%$ caecal extract. The medium contained $0.4 \%$ mucin as the substrate. Two-day bacterial cultures were centrifuged at $5000 \mathrm{rpm}$ for $40 \mathrm{~min}$, and cell-free supernatant collected for extracellular enzymes activity assays. Equal amounts of the supernatant and $2 \%$ mucin solution in $0.1 \mathrm{M}$ phosphate buffer were mixed and incubated at $39{ }^{\circ} \mathrm{C}$ with or without $\mathrm{CaCl}_{2}$ addition $(0.5 \%$ final concentration). Activity of mucin lyase was assayed according to Linker (1966), and expressed as nmol of unsaturated products released per min. per mg of protein. In accordance with Colmer et al. (1988), we supposed that the molar extinction coefficient of unsaturated products (double bonds) was $4600 \mathrm{dm}^{3} \cdot \mathrm{mol}^{-1} \cdot \mathrm{cm}^{-1}$. Activity of mucin hydrolase was assayed by spectrophotometric determination of reducing sugars released from mucin using the method of Lever (1977).

The $t$-test was used to evaluate differences in proportions of morphological types of mucinolytic bacteria isolated from Hyplus and crossbred rabbits. 


\section{Results and Discussion}

The number of mucinolytic bacteria in caecal samples was $5.96 \pm 3.79 \times 10^{6} \mathrm{cfu}$ per $\mathrm{g}$. Relatively low counts of mucinolytic bacteria contrast with high fermentability of mucin in mixed cultures of rabbit caecal microorganisms (Marounek et al. 2000). Most of mucinolytic bacteria in the rabbit caecum, thus, may be non-cultivable, i. e. not able to grow in pure cultures, without interactions with other microbes. Gram-negative irregular rods were the most numerous mucinolytic isolates in this study, followed by gram-negative cocci and short rods, grampositive rods, gram-positive cocci and gram-positive spore-forming rods (Table 1). Differences between commercial (Hyplus) and crossbred rabbits were mostly small in spite of the fact that rabbits were fed different diets. Significantly higher proportion of gram-positive sporeforming rods, however, was found among mucinolytic isolates from caeca of Hyplus rabbits $(P<0.05)$.

Nine strains out of 31 isolates examined were identified at the species level. Their biochemical characteristics are shown in Table 2. According to current taxonomic criteria, gram-negative isolates MB2, MB4, MB5 and MB9 were identified as Mitsuokella multiacidus (formerly Bacteroides multiacidus), and strains MA2, MA5, MK6 and MK7 as

Table 1

Proportions of various morphological types of mucinolytic bacteria in caeca of rabbits

\begin{tabular}{|l|l|l|l|}
\hline Type & Hyplus rabbits & Crossbred rabbits & All rabbits \\
\hline Gram-negative irregular rods & $0.349 \pm 0.052$ & $0.335 \pm 0.018$ & $0.341 \pm 0.032$ \\
Gram-negative cocci and short rods & $0.206 \pm 0.056$ & $0.240 \pm 0.031$ & $0.225 \pm 0.041$ \\
Gram-positive rods & $0.143 \pm 0.091$ & $0.196 \pm 0.047$ & $0.173 \pm 0.066$ \\
Gram-positive cocci & $0.163 \pm 0.020$ & $0.169 \pm 0.024$ & $0.166 \pm 0.021$ \\
Gram-positive sporeforming rods & $0.137 \pm 0.024^{\mathrm{a}}$ & $0.064 \pm 0.041^{\mathrm{b}}$ & $0.095 \pm 0.040$ \\
\hline
\end{tabular}

Mean values for 3 Hyplus and 4 crossbred rabbits \pm SD; total number of isolates 230

${ }^{\mathrm{ab}}$ Significant difference between Hyplus and crossbred rabbits $(P<0.05)$
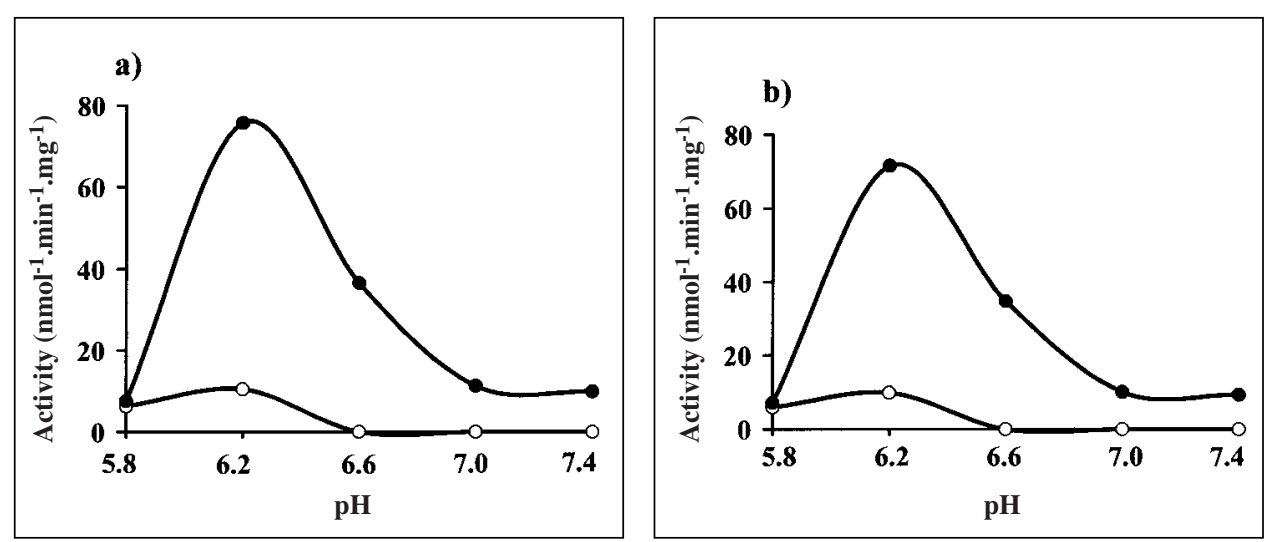

Fig.1. Effect of $\mathrm{pH}$ and $\mathrm{Ca}^{++}$ions on activity of mucin lyases in Mitsuokella multiacidus, strains MB2 (a) and MB9 (b). Enzymatic reactions were carried out with $(\bullet)$ or without $(\odot) \mathrm{CaCl}_{2}$ addition. Activity was expressed as nmol of unsaturated products released per min. per mg of protein.

Bacteroides capillosus. Nucleic acids of the MK7 isolate, however, did not hybridize with the Bacteroides/Prevotella fluorescent probe. The taxonomy of this isolate, thus, remains uncertain. One gram-negative isolate, unidentified at the species level (MA1 strain), hybridized with fluorescently labelled Bacteroides/Prevotella probe. Identification of grampositive bacteria was suscesful in one isolate only. Strain MA3 was identified as 
Table 2

Biochemical characteristics ${ }^{\mathrm{a}}$ of rabbit mucinolytic isolates

\begin{tabular}{|c|c|c|c|c|c|c|c|c|c|}
\hline Parameter & MA2 & MA3 & MA5 & MB2 & MB4 & MB5 & MB9 & MK6 & MK7 \\
\hline Gram staining & - & + & - & - & - & - & - & - & - \\
\hline $\mathrm{H}_{2} \mathrm{~S}$ production & - & - & - & - & - & - & - & - & - \\
\hline Indol production & - & - & - & - & - & - & - & - & - \\
\hline Nitrate reduction & - & - & - & + & + & \pm & + & - & - \\
\hline Aesculin & + & + & + & + & + & + & + & + & + \\
\hline Mannose & + & + & - & + & + & + & + & - & - \\
\hline Maltose & - & + & - & + & + & + & + & - & - \\
\hline Salicin & - & + & - & + & + & + & + & - & - \\
\hline Raffinose & - & - & - & + & + & + & + & - & - \\
\hline Fructose & - & + & - & + & + & + & + & - & - \\
\hline Trehalose & - & + & - & + & + & + & + & - & + \\
\hline Cellobiose & - & + & - & + & + & + & + & - & - \\
\hline Galactose & - & + & - & + & + & + & + & - & - \\
\hline Mannitol & - & + & - & + & + & + & + & - & - \\
\hline Xylose & - & + & - & + & + & + & + & - & - \\
\hline Lactose & - & - & - & + & + & + & + & - & - \\
\hline Rhamnose & - & - & - & + & + & - & + & - & - \\
\hline Arabinose & - & + & - & + & + & + & + & - & - \\
\hline Melezitose & - & - & - & + & + & + & + & - & - \\
\hline Sorbitol & - & + & - & - & + & - & + & - & - \\
\hline Melibiose & - & - & - & + & + & + & + & - & - \\
\hline Urease & + & - & + & - & + & - & - & + & + \\
\hline Catalase & + & - & + & + & + & + & + & + & + \\
\hline Growth in bile & + & - & + & + & + & +++ & + & + & + \\
\hline End - products ${ }^{b}$ & $\begin{array}{l}\mathrm{a}, \mathrm{l} \\
\mathrm{p}, \mathrm{s}\end{array}$ & $\begin{array}{c}\mathrm{A}, 1, \\
\mathrm{~S}\end{array}$ & $\begin{array}{l}\mathrm{a}, 1, \\
\mathrm{p}, \mathrm{s}\end{array}$ & $\begin{array}{c}\mathrm{L}, \mathrm{A}, \\
\mathrm{S}\end{array}$ & $\mathrm{L}, \mathrm{A}$ & $\begin{array}{c}\mathrm{L}, \mathrm{A}, \\
\mathrm{S}\end{array}$ & $\begin{array}{c}\mathrm{L}, \mathrm{A}, \\
\mathrm{S}\end{array}$ & $\mathrm{a}, 1, \mathrm{~s}$ & $\begin{array}{l}\mathrm{a}, \mathrm{l}, \\
\mathrm{p}, \mathrm{s}\end{array}$ \\
\hline
\end{tabular}

a See Materials and Methods

b Metabolites of glucose: a - acetate, 1 - lactate, $\mathrm{p}$ - propionate;

capital letters indicate concentrations $>10 \mathrm{mM}$, small letters $<10 \mathrm{mM}$.

Actinomyces izraeli. Only this strain does not belong to Bacteroidaceae. No strain belonging to the Clostridium genus was found.

Mucinolytic bacteria produce a range of proteolytic and glycosidic enzymes that play a role in the degradation of host-derived glycoproteins (e.g. Rafay et al. 1996). Fig. 1 shows activity of lyases involved in the degradation of mucin in two bacteria growing on mucin to the highest optical density. Activities of lyases in M. multiacidus strains MB2 and MB9 were similar, with the $\mathrm{pH}$-optimum at 6.2. Calcium ions were necessary for their function. Activity of mucin hydrolase was not found in these strains.

It follows from our results that bacteria M. multiacidus, B. capillosus and A. izraeli participate in the fermentation of mucin, which is one of substrates coming to the hindgut from the small intestine and secreted by goblet cells. As shown in Table 2, B. capillosus isolates were less versatile (i.e. fermenting a limited number of substrates) than those of M. multiacidus and A. izraeli. Attempts to identify other mucinolytic isolates failed as their phenotypic characteristics did not correspond to any previously described species. In our opinion, information on the complex microflora in the rabbit coecum is far from complete and novel species may be present in the rabbit digestive tract. This has similarly been shown 
to be the case for the equine large intestine, as the analysis of 16S ribosomal RNA gene sequences from samples of intestinal wall and lumen contents showed that only $5 \%$ of the sequence corresponded to known organisms (Daly et al. 2001).

\section{Isolace, identifikace a charakterizace mucinolytických bakterií ze slepého střeva králíků}

Z obsahů slepých střev sedmi králíků jsme získali 230 bakteriálních isolátů, schopných růst $\mathrm{v}$ médiu s mucinem ze žaludku prasete. Největší zastoupení měly gram-negativní nepravidelné tyčinky $(34,1 \%)$, následované gram-negativními koky a krátkými tyčinkami (22,5\%), gram-positivními tyčinkami $(17,3 \%)$, gram-positivními koky $(16,6 \%)$ a grampositivními sporotvornými tyčinkami $(9,5 \%)$.Třicetjeden isolát jsme se pokusili identifikovat na základě morfologie, výsledků biochemických testů a tvorby metabolitů. Navíc jsme bakteriální buňky hybridizovali s fluorescenčně značenými sondami pro rody Bacteroides/Prevotella a Clostridium. Čtyřri isoláty se podařilo identifikovat na úrovni druhu jako Mitsuokella multiacidus, tři jako Bacteroides capillosus a jeden jako Actinomyces izraeli. Vyjma posledního, identifikované kmeny př́sluší $\mathrm{k}$ čeledi Bacteroidaceae. Jeden isolát jsme na základě výsledku hybridizační zkoušky mohli přiřadit k rodu Bacteroides/Prevotella, bez bližšího druhového určení. Ostatní isoláty se nepodařilo identifikovat, nebot jejich fenotypické charakteristiky neodpovídaly známým bakteriálním druhům. Mezi neidentifikovanými isoláty nebyl žádný zástupce rodu Clostridium. U dvou kmenů $M$. multiacidus, které na mucinu rostly nejlépe, jsme zjistili vysokou aktivitu mucin lyas. Optimální $\mathrm{pH}$ jejich účinku bylo 6,2. Aktivita byla podmíněna prítomností $\mathrm{Ca}^{++}$iontů.

\section{Acknowledgement}

This study was supported by the Ministry of Education, Youth and Sports (programme COST, project 848.001).

\section{References}

BAYLISS, CE, HOUSTON, AP 1984: Characterization of plant polysaccharide- and mucin-fermenting anaerobic bacteria from human feces. Appl Environ Microbiol 48: 626-632

COLLMER, A, RIED, JL, MOUNT, MS 1988: Assay methods of pectic enzymes. In: Wood, WA, Kellog, ST: Methods in Enzymology, vol. 161. Academic Press, San Diego, pp. 329-334

CROCIANI, F, ALESSANDRINI, A, MUCCI, MM, BIAVATI, B 1994: Degradation of complex carbohydrates by Bifidobacterium spp. Int. J Food Microbiol 24: 199-210

DALY, K, STEWART, CS, FLINT, HJ, SHIRAZI-BEECHEY, SP 2001: Bacterial diversity within the equine large intestine as revealed by molecular analysis of cloned 16S rRNA genes. FEMS Microbiol Ecol 38: 141-151

EMALDI, O, CROCIANI, F, MATTEUZZI, D 1979: A note on the total viable counts and selective enumeration of anaerobic bacteria in the caecal content, soft and hard faeces of rabbit. J Appl Bacteriol 46: 169-172

FADDIN, JFM 1976: Biochemical Tests for Identification of Medical Bacteria. The Williams \& Wilkins Comp., Baltimore, pp. 1-204

HERBERT, D, PHIPPS, PJ, STRANGE, RE 1971: Chemical analysis of microbial cells. In: Norris, JR, Ribbons, DW: Methods in Microbiology, vol. 5B. Academic Press, London, pp. 209-344

HILL, RRH 1986: Digestion of mucin polysaccharides in vitro by bacteria isolated from the rabbit cecum. Curr Microbiol 14: 117-120

HOLMES, JHG, BAYLEY, HS, LEADBEATER, PA 1974: Digestion of protein in small and large intestine of the pig. Br J Nutr 32: 479-489

LEVER, M 1977: Carbohydrate determination with 4-hydroxybenzoic acid hydrazide (PAHBAH): effect of bismuth on the reaction. Anal Biochem 81: 21-27

LEWETT, PN 1978: Anaerobic Microbiology - a Practical Approach. Oxford University Press, Oxford, p. 303.

LINKER, A 1966: Bacterial mucopolysaccharidases (mucopolysaccharide lyases). In: Neufeld, EF, Ginsburg, V: Methods in Enzymology, vol. VIII, Academic Press, New York and London, pp. 650-654

MAROUNEK, M, SKŘIVANOVÁ, V, DUŠKOVÁ, D 2000: In vitro caecal fermentation of nitrogenous substrates in rabbits. J Agric Sci, Camb 135: 437-442

MAROUNEK, M, PETR, O, ŠIMU゚NEK, J 1993: Monensin has no effect on growth and metabolism of Megasphaera elsdenii. Folia Microbiol (Praha) 38: 383-386 
RAFAY, AM, HOMER, KA, BEIGHTON, D 1996: Effect of mucin and glucose on proteolytic and glycosidic activities of Streptococcus oralis. J Med Microbiol 44: 409-417

SALYERS, AA, LEEDLE, JAZ 1983: Carbohydrate metabolism in the human colon. In: HENTGES, DJ: Human Intestinal Microflora in Health and Disease. Academic Press, New York, pp. 129-146

SALYERS, AA, VERCELLOTTI, JR, WEST, SEH, WILKINS, TD 1977: Fermentation of mucin and plant polysaccharides by strains of Bacteroides from the human colon. Appl Environ Microbiol 33: 319-322 